\title{
Una poesía desconocida de Plácido
}

Muchos de los poemas de Gabriel de la Concepción Valdés, el célebre poeta cubano de principios del siglo pasado, se han extraviado debido principalmente a dos circunstancias: primero, Plácido con frecuencia improvisaba en reuniones y tertulias pero, aunque sus amigos aprendieran de memoria los resultados y los diseminaran verbalmente, algunas de dichas improvisaciones nunca fueron escritas; y segundo, muchas de sus poesías impresas aparecieron en periódicos cubanos de provincias. Más tarde algunas de esas poesías fueron recogidas en las colecciones, en las "obras completas"; pero, en general, las que no fueron recopiladas de ese modo se han perdido, porque muchos de esos periódicos no se conservan.

Por ejemplo, sólo una pequeña parte de la poesía que por primera vez se publicó en La Aurora de Matanzas, el periódico que en I837 Plácido ayudó a redactar, fue incluida en la primera colección de sus versos (Matanzas, I838, aunque cierto biógrafo afirma que tal colección no apafeció hasta 1839), o en las siguientes. ${ }^{1}$ García Garófalo Mesa, en la más detallada de las biografías en español acerca de Plácido, observa que tampoco se conocen hoy algunos de los poemas impresos en otro periódico de provincia, El Eco de Villa-Clara (de cuya redacción Plácido formó parte en $184^{\circ}$ ), que no fueron recogidos en la última colección de sus obras, aparecida en La Habana, en I886, con prólogo de Sebastián Alfredo de Morales, uno de los primeros críticos y biógrafos del poeta cubano. ${ }^{2}$

Una de estas obras, hasta ahora desconocida, puede que sea un poema, al parecer de encargo, publicado en la edición del 8 de agosto de 1879 de otro periódico matancero, El Diario de Matanzas, del que se conserva

1 Enrique Piñeyro, "Gabriel de la Concepción Valdés", Biografías americanas (París, sin fecha), pág. 337.

2 Plácido, poeta y mártir (México, 1838), págs. 47 y 60. 
un ejemplar en la Biblioteca Pública Gener y Del Monte, de Matanzas. ${ }^{3}$ Dicha composición lleva por título "En los días / De D. José Florencio García / (Poesía inédita de Plácido)". Al final está apuntada la fecha "Marzo I9 de I839" y va firmada con el seudónimo de "Un amigo".

Por su fecha, I839, puede creerse que sea obra de la época en que Plácido actuaba en Matanzas de redactor de la Aurora. Por supuesto es hoy un misterio determinar la manera en que, cuarenta años después, los editores del Diario descubrieron esta poesía. Tal vez la recogieran de un periódico antiguo, como la Aurora, y simplemente volvieran a imprimirla; y por "inédita" quizás quisieron decir que no había aparecido en libro alguno, sentido que Morales da a dicha palabra en su edición de I886.* Más probable, sin embargo, es que la obtuvieran localmente, de la familia del patrón García, o de algún amigo de Plácido, o de los descendientes de uno u otro. En todo caso, es desconocida porque no sólo la omiten todas las colecciones, sino que también las relaciones de la vida y las obras de Plácido (tanto en español como en inglés) no hacen referencia alguna a ella.

Es una silva irregular, forma a veces empleada por Plácido en fábulas, odas y poemas de encargo. La obra está llena de símiles, metáforas e invenciones literarias que parecen haber fluido fácilmente de los labios del poeta; este estilo ornamentado y sentimental refleja la influencia de varios poetas peninsulares, pre-románticos y románticos del siglo decinueve, sobre todo la de Francisco Martínez de la Rosa, cuya influencia sobre Plácido ya fue notada por el más reciente de sus biógrafos y críticos. ${ }^{6}$

A pesar de la falta de sinceridad posiblemente visible en la mayor parte de la poesía escrita de encargo, tal poesía en el caso de Plácido (como observa su único biógrafo en inglés), no puede ser "dismissed

3 Según una carta del 16 de octubre de 1958 que me enviaron de la Biblioteca Francisco de Paula Coronado, de La Habana, la biblioteca matancera posee el único ejemplar de este periódico. Un segundo ejemplar del poema se encuentra en forma de recorte pegado con cola en la carátula de un libro existente en la Biblioteca Nacional, de La Habana: Poesías completas de Plácido (París: Mme C. Denné Schmitz e Hijo [Calle Favart, 2], 1862).

4 A. M. Eligio de la Puente, "Introducción", Poesías selectas de Plácido (La Habana, 1930), pág. xxx.

5 La única lista completa de ediciones placidianas se encuentra en ibid., págs. xix-xxxii. En inglés la única biografía más o menos completa es: Ben C. Carruthers, "The Life, Work and Death of Plácido" (Tesis doctoral, inédita, University of Illinois, 1941). La más reciente en español es la de Jorge Casal, Plácido como poeta cubano (La Habana, 1944).

6 Casals, págs. 26-27. Véase también Salvador Salazar y Roig, El dolor en la lírica cubana (La Habana, 1925), pág. 20, citado por Carruthers, pág. 106. 
with a shrug of the shoulders", porque hoy día muchos de esos versos de encargo son considerados entre lo mejor de su producción." Además, este ejemplo constituye aun más prueba de una capacidad innata y de un poder creador que parecen increíbles en una persona tan joven y casi analfabeta. $\mathrm{Y}$ hace que uno se pregunte qué grandeza, a pesar de su falta de educación académica, hubiera alcanzado este vate y escultor de peines de carey -tres veces condenado, por su color, su pobreza y su ilegitimidad- si no hubiera sido ejecutado insensatamente, a la edad de treinta y cinco años, por orden de un gobierno que temía una insurrección negra.

Ya el caracol sonante

Que ufano tañe entre la mar sombría

El incansable pescador, la fría

Serena faz del alba fulgurante

Que de aljófar partículas rocía,

$Y$ el gorjear del ruiseñor amante,

La vuelta anuncian de tu fausto día.

Salud, Florencio: tu pasada vida Inmaculada fue, luciente y pura Como el sol tropical; la frente erguida Alzar puedes cual palma en la llanura; Que quien de un padre las cenizas honra $Y$ á costa de sudores y fatigas Los créditos cubriendo su honor salva, Justo será que el cielo le bendiga.

$Y$ cuando al hado su existir sucumba, A sus hijos legando tal ejemplo, Ellos dirán llorosos en su tumba:

"Gloria es su nombre, su memoria un templo".

Diganlo entonces: la amistad en tanto

Pulse su lira de marfil sonora,

$Y$ al vislumbrar la nacarada aurora

Que tu cuna cubrió con su áureo manto,

De paz, vida y salud entone el canto.

Empero ¿qué of recerte el alma mía

Puede en tu Oriente como digna of renda

Que no vacile al darlo mi alegría?

Una flor... sí, una flor, la que primero

Parezca ante mis ojos.

¡Salve, jazmín nevado

Muy más feliz que los claveles rojos,

Sencillo emblema del candor sagrado.

7 Carruthers, pág. 197. Véase también Domingo Figueroa-Caneda, Plácido, poeta cubano (La Habana, 1922), pág. 95. 
Lleva en tus alas, cefirillo blando Donde mi caro y respetable amigo, Esta cándida flor, y revolando Sé de su dicha espléndido testigo. Dirásle que por ti, salud le mando, $X$ que por los largos años y felices Quiera el cielo que en justa tecompensa De tu virtud presente y la pasada, Goce tranquilo del placer futuro A par de su consorte idolatrada, $Y$ acoia grato, de mi fé seguro, Este blanco jazmín, fragante y puro Con que le brinda la Amistad sagrada.

FREDERICK S. STIMSON, Universidad de Nortbwestern. 